\title{
Groundwater resources in Brazil: a review of possible impacts caused by climate change
}

\author{
RICARDO HIRATA ${ }^{1,2}$ and BRUNO P. CONICELLI ${ }^{2}$ \\ ${ }^{1}$ Groundwater Research Center (CEPAS), Instituto de Ciências da Terra, Universidade de São Paulo, \\ Rua do Lago, 562, Cidade Universitária, 05508-080 São Paulo, SP, Brasil \\ ${ }^{2}$ Laboratório de Modelos Físicos, Instituto de Ciências da Terra, Universidade de São Paulo, \\ Rua do Lago, 562, Cidade Universitária, 05508-080 São Paulo, SP, Brasil
}

Manuscript received on September 14, 2010; accepted for publication on April 5, 2011

\begin{abstract}
Groundwater has a strategic role in times of climate change mainly because aquifers can provide water for long periods, even during very long and severe drought. The reduction and/or changes on the precipitation pattern can diminish the recharge mainly in unconfined aquifer, causing available groundwater restriction. The expected impact of long-term climate changes on the Brazilian aquifers for 2050 will lead to a severe reduction in $70 \%$ of recharge in the Northeast region aquifers (comparing to 2010 values), varying from $30 \%$ to $70 \%$ in the North region. Data referring to the South and Southeast regions are more favorable, with an increase in the relative recharge values from $30 \%$ to $100 \%$. Another expected impact is the increase in demand and the decrease in the surface water availability that will make the population turn to aquifers as its main source of water for public or private uses in many regions of the country. Thus, an integrated use of surface and groundwater must therefore be considered in the water use planning. The solution of water scarcity is based on three factors: society growth awareness, better knowledge on the characteristics of hydraulic and chemical aquifers and effective management actions.
\end{abstract}

Key words: Drought, groundwater, aquifer recharge, integrated use of water, water resources management.

\section{INTRODUCTION}

The climate change directly interferes in the hydrologic cycle by altering the pluviometric regime and evapotranspi- ration in a region, influencing the process of aquifer recharge and modifying river flows. It can either increase available resources or just reduce it with time. The climate change itself, with temperature changes and other environmental factors, can also indirectly interfere in it, affecting the relation between society and the productive

Correspondence to: Ricardo Hirata

E-mail:rhirata@usp.br sector and water resources, modifying the demand or demanding water with other physical, chemical or biological characteristics. Both direct and indirect effects will need a better use of water resources. In order to achieve it, it is necessary to re-think the hydraulic matrix and social, economic and environmental efficiency of the resource and its present and future use.

Groundwater has a strategic role in times of climate change. Due to their characteristics, aquifers can provide water for long periods, even during very long droughts. 
A demand for quality water also follows the population growth and the country development. The vulnerability to surface water contamination and the difficulty in remediating aquifers emphasize the protection importance of these resources so as to keep their quality in a future of climate uncertainty.

However, groundwater has not only a strategic role; it is also of great importance regarding the water supply in Brazilian cities and communities (Hirata et al. 2010). Total (static) groundwater reserves in the Brazil amount to approximately 112 thousand $\mathrm{km}^{3}$ (Rebouças 1999), and renewable reserves (i.e., effective discharge) to $42,289 \mathrm{~m}^{3} / \mathrm{s}\left(1,334 \mathrm{~km}^{3} / \mathrm{a}\right)$, corresponding to $24 \%$ of the river flow in the country (annual average flow $179.433 \mathrm{~m}^{3} / \mathrm{s}$ ) and to $49 \%$ of the drought flow (considered as a drought flow with a $95 \%$ permanence). Only the 27 main sedimentary aquifers, which occupy $32 \%$ of the country, totalize $20,437 \mathrm{~m}^{3} / \mathrm{s}$ (ANA 2005a, b, Hirata et al. 2006).

There are about 416,000 wells in the country, with an annual increase of 10,800 new ones, supplying from 30 to $40 \%$ of the population (ANA 2005a). Water from tubular wells and springs has been used for various purposes, such as human and animal supply, industry, irrigation and leisure.

It is important to stress that a significant part of the household connected to the main public water supply makes use of groundwater in urban areas (Foster et al. 2009). Although this use is complementary to the surface water exploitation in many large cities, groundwater is the main source of water in other small to medium size urbanizations and also plays an important role in the socioeconomic development of the country. In Brazil, $15.6 \%$ of the household use only groundwater, $77.8 \%$ use the public (surface and groundwater) water supply systems, and 6.6\% use other forms of supply (IBGE 2002). There is a reason to believe that these numbers may be underestimated due to the lack of good statistic data and also to the awareness of part of the population and even the government.
In the state of São Paulo, 462 (71.6\%) of the 645 municipalities are supplied totally $(47,7 \%)$ or partially $(23,9 \%)$ with groundwater, including large cities like Ribeirão Preto, Marília, São José dos Campos and São José do Rio Preto. About 5.5 million people in the state are supplied daily with groundwater (Silva et al. 1998). In the states of Maranhão and Piauí, more than $70 \%$ and $80 \%$ of the cities, use water from wells, respectively (ANA 2005a).

Groundwater serves rural communities in the semi-arid Northeast regions, as well as urban populations in various capitals such as Manaus, Belém, Fortaleza, Recife, Natal, Porto Velho, Fortaleza and Maceió. It is also widely exploited for irrigation in Mossoró (Rio Grande do Norte), in the Irecê regions (Bahia) and in the border between Rio Grande do Norte and Ceará, where it is used mainly to cultivate fruits for exportation. In the metropolitan region of São Paulo, groundwater is consumed by industries, residential condominiums, hospitals and hotels. Although it amounts to only $17 \%$ of the total water distributed by the public system, the loss of this resource would cause the collapse of the public supply, once the public system operates at a maximum capacity. So, groundwater pumped from 12,000 wells, $70 \%$ of which are illegal, guarantees the integrity of water supply for the Upper Tietê River Basin, where the city of São Paulo is located (Hirata et al. 2002, ANA 2005a, b).

Another important aspect of the peri-urban supply is that groundwater is sometimes the only source of available water for the poor populations, despite its dubious quality. The same occurs in a small urbanization, for rural population and agricultural villages, as well as in facilities far from the public water supply system, such as airports, service stations and country hotels.

Groundwater is still responsible for tourism in the form of thermal water centers in cities like Caldas Novas (Goiás), Araxá, São Lourenço and Poços de Caldas (Minas Gerais), and Lindóia (São Paulo). Mineral water is now widely used in 
urban centers due to its image of superior quality, accounting for a market of more than US\$ 450 million per year (Queiroz 2004). These are only some examples of the important participation of groundwater in its various uses (ANA 2005a).

However, the great importance of its resources for the social and economic development of the population contrasts with the lack of awareness of the potential and the stage of exploitation of the aquifers in the country, making it a great challenge for adequate water management. There are particularly no specific studies about the impact of climate change on aquifers, both on their recharge and on pressures associated to their increase in demand. This situation is worsened by the fact that the knowledge on the real potential of this resource is not complete and does not extend all over the country to allow a good resource management. Due to this situation, the purpose of this work is to evaluate, in a preliminar and regional scale, the potential impacts that are expected because of the climate change on aquifers, indicating, above all, regions where systematic analyses are necessary to reduce these impacts.

\section{COMPLEMENTARY CHARACTERISTICS OF GROUNDWATER AND} SURFACE WATER

A relevant aspect to be considered is that groundwater dynamics is different from surface water. The river, from the point of view of the water resource manager, is the "opposite" of the aquifer (Table I). The river has a low capacity to store water, but, on the other hand, it can deliver a much larger instant discharge than aquifers. Additionally, the aquifer exploitation is done through wells and springs that usually have stable flows (little influenced by seasonal changes), but they are usually reduced in volume when compared to surface water pumping.

Groundwater exploitation is still characterized by less financial investment and by allowing scaled solutions (one well after the other) in the
TABLE I

"Opposite" characteristics of groundwater and surface water

\begin{tabular}{|c|c|}
\hline Rivers & Aquifers \\
\hline $\begin{array}{c}\text { Small reserve (less } \\
\text { than } 1 \% \text { of fresh, liquid } \\
\text { water in the planet) }\end{array}$ & $\begin{array}{c}\text { Great storage capacity } \\
\text { (95\% of the water) }\end{array}$ \\
\hline $\begin{array}{c}\text { Deliver instantly a great } \\
\text { amount of water }\end{array}$ & $\begin{array}{c}\text { Allow pumping from } \\
\text { low-flow wells }\end{array}$ \\
\hline $\begin{array}{c}\text { Hardly allow for scaled } \\
\text { or modular solutions }\end{array}$ & $\begin{array}{l}\text { Allow the building of a } \\
\text { sequence of wells that } \\
\text { serve the needs }\end{array}$ \\
\hline $\begin{array}{l}\text { Need costly water } \\
\text { treatment stations }\end{array}$ & $\begin{array}{c}\text { Do not need treatment } \\
\text { (except locally } \\
\text { chlorination) }\end{array}$ \\
\hline $\begin{array}{c}\text { Need water treatment } \\
\text { before distribution }\end{array}$ & $\begin{array}{c}\text { Have excellent natural } \\
\text { quality (all bottled } \\
\text { water is groundwater) }\end{array}$ \\
\hline Very popular & Little known \\
\hline $\begin{array}{l}\text { Receive many } \\
\text { investments }\end{array}$ & Few investments \\
\hline $\begin{array}{l}\text { Very vulnerable to } \\
\text { contamination }\end{array}$ & More protected \\
\hline
\end{tabular}

installation of large-scale supply systems, even for independent and atomized systems. Surface water pumping, on the other hand, needs more substantial initial investments and it is not so flexible. Yet, costs of pumping and electric energy make groundwater less competitive where the aquifer transmissibility is low, where dynamic levels are deep or where the demand is high and the well yield is low (Hirata et al. 2010).

These two different water dynamics are not widely used in Brazil. Even in cities that use both water sources, there is still no integrated planning that will explore the advantages of each resource, and the usage of two or more water sources does not aim 

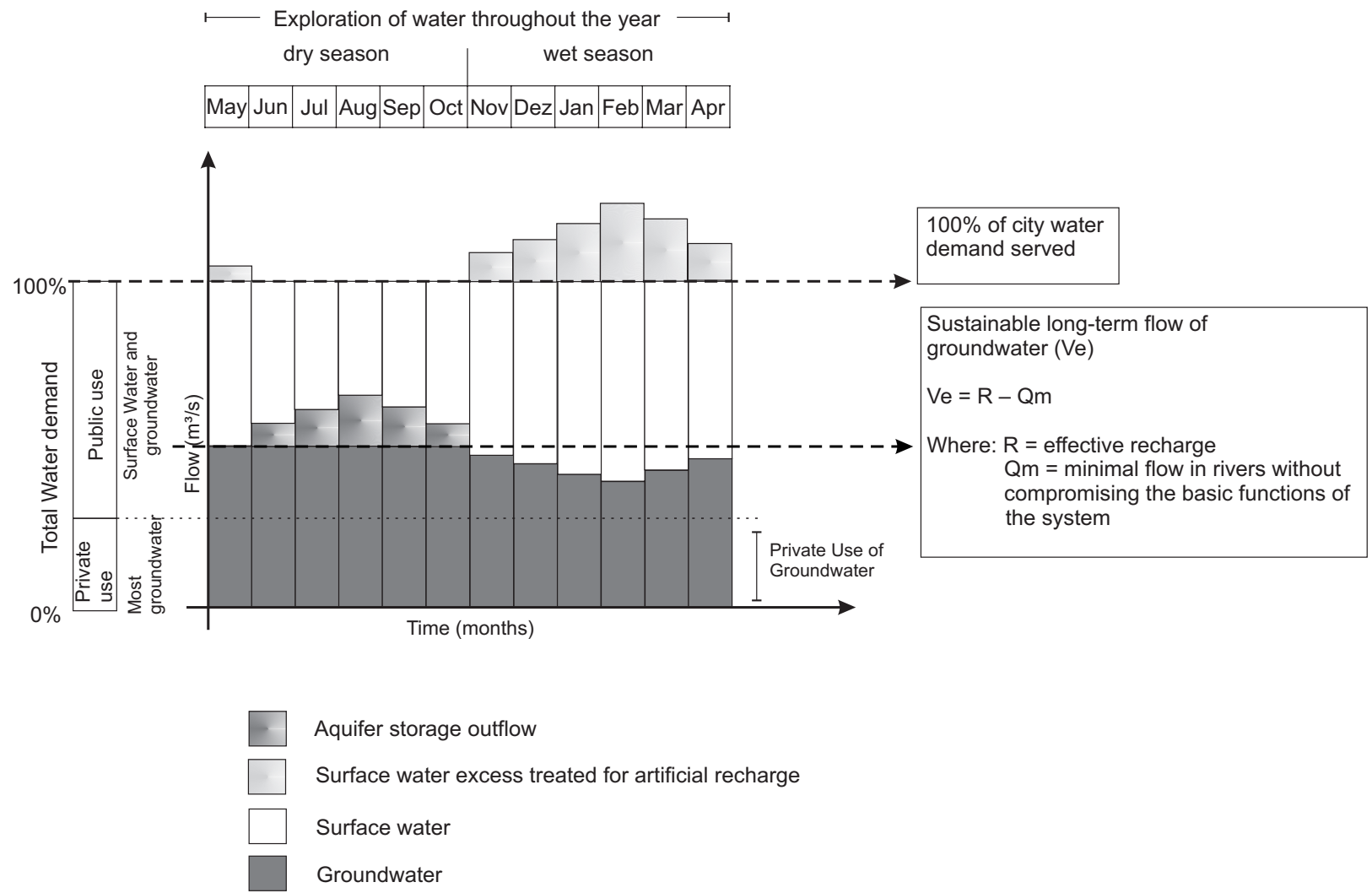

Figure 1 - Theoretical scheme of the integrated use of surface water and groundwater.

at lower cost or better environmental use of the water cycle (Figure 1). In some cities like Madrid (Spain), the system operated by Canal de Santa Isabel II uses excess treated surface water in the rainy season to recharge the aquifer after the period when it is most demanded (in drought), which is when rivers do not have enough water and groundwater supplies the city (Camacho and Martín 2000).

This complementary aspect (Table I) must therefore be considered in the water use planning, which obvious benefits the society and the users. It is necessary, then, to prepare cities and economy sectors that require water for an increase in the groundwater use because of the surface water degradation resources and climate changes that create irregularities in the wet/dry seasons or even increase the demand for water.

\section{IMPACTS ON AQUIFERS}

As demonstrated by the International Panel on Climate Change (IPCC 2007), Brazil is vulnerable to present and future climate changes. The most vulnerable areas ar the Amazon and the Northeast regions, where, according to the average data of global climate models of the Fourth Assessment Report (AR4) of the IPCC, a decrease in rainfall is likely to occur extensively in these regions (IPCC 2007).

Rainfall tendencies observed in the IPCC AR4 are correlated to the projected South American river flow, where the Paraná-Prata River and other rivers in Southeast South America (including the Eastern Brazilian coast) tend to experience a flow increase. Milly et al. (2005) analyzed river flows in various IPCC AR4 models for the 21 st century in relation to 
the present and suggest flow reductions for the São Francisco, Parnaíba, Tocantins, Xingu and other rivers in the East of the Amazon State (Figure 2).

As observed in Figure 2, a flow decrease in some of the main rivers of the North and Northeast regions of Brazil coincides with areas of important regional aquifer systems (figure 3) such the Barreiras, Alter do Chão, Jandaíra, Beberibe, Itapecuru and Bambuí. According to IPCC AR4, the west of the Amazon

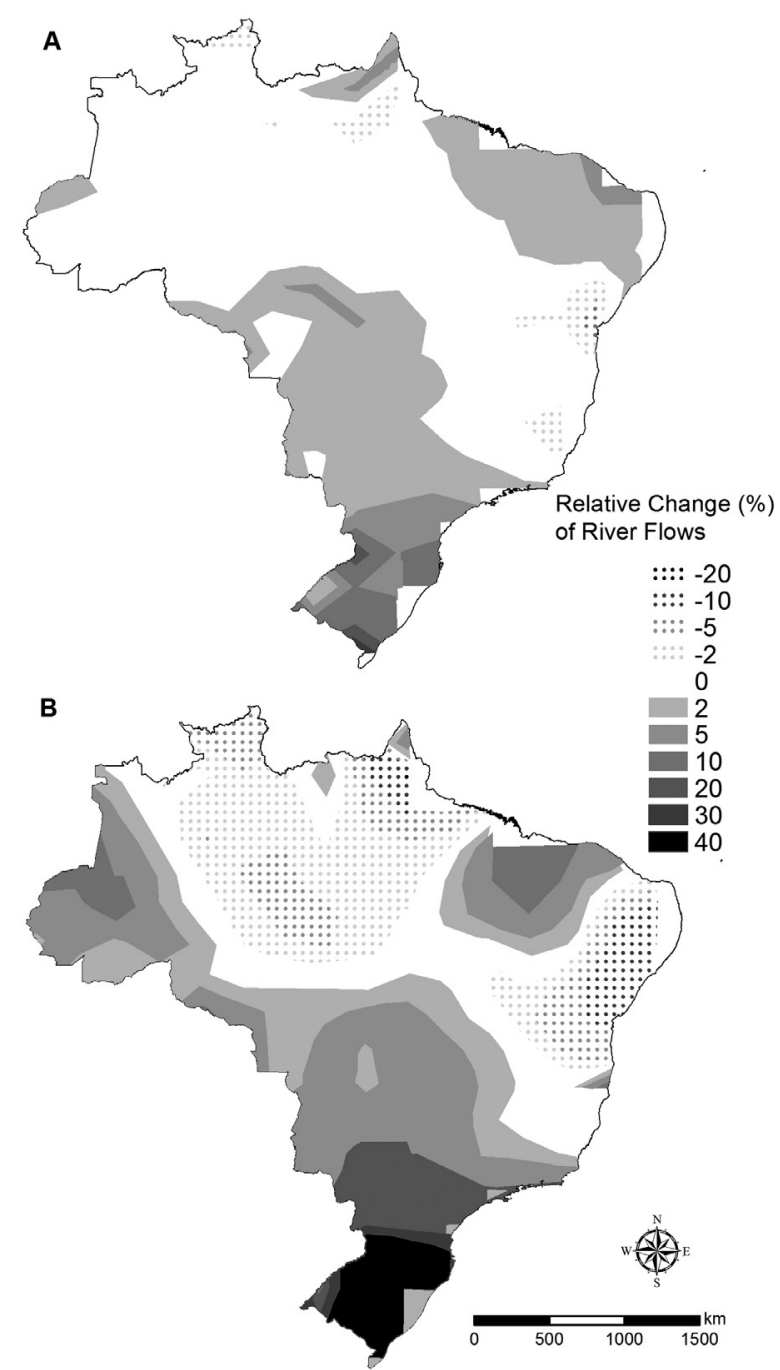

Figure 2 - (A) Relative change (\%) of river flows in Brazil for the period of 1971-2000. (B) Relative change (\%) of river flows in Brazil for the period of 2041-2060 of scenario A1B relative to the 1900-1998 average (IPCC AR4 average of nine global models, round 20C3M) (adapted from Milly et al. 2005). and the South and Southeast regions of Brazil will suffer from a higher frequency of rainfall extremes. In the period of 2080-2099, relative to 1980-1999, there is a higher tendency toward dry consecutive days in the east of the Amazon and in the Northeast and Southeast regions, whereas extremes of intense rainfall will intensify the rainy days in the west of the Amazon (Marengo Orsini 2008). Although there will be more rain in some regions in Brazil, the rainfall distribution will still vary, sometimes causing longer drought periods as observed in 2005 in the Amazon region. This means that water tends to be concentrated in specific periods. There will be more water, but it will have a more heterogeneous distribution throughout the year. So, aquifers in these regions can contribute to the regularization of water supply to go through long periods of drought, particularly in Guarani, Serra Geral, Bauru-Caiuá, Barreiras, Alter do Chão, Urucuia-Areado, Itapecuru and Bambuí aquifer systems. In times of scarcity, aquifers become safe sources of water for supplying local population and for economic activities including irrigated agriculture. However, more demand for the groundwater resource exploitation affects aquifers and also the surface water (lakes, rivers, reservoirs) by reducing base flows and consequently reducing biodiversity and impacting other systems that depend on stable water levels in reservoirs, lakes and rivers.

The climate change has affected the aquifer recharge and the surface discharge. Temperature rise has the potential to reduce the total discharge in function of the elevation of evapotranspiration, as well as the discharge due to the reduction of water excess. Döll and Flörke (2005) consider the alterations in rainfall throughout the seasons as the main factor influencing aquifer recharge.

The impact on temporal variability increase on the aquifer is closely related to the local conditions. The increase in rainfall has the potential to increase aquifer recharge, but evapotranspiration can cancel this factor mainly in semi-arid regions. Döll and Flörke (2005) observed that temporal variability in 


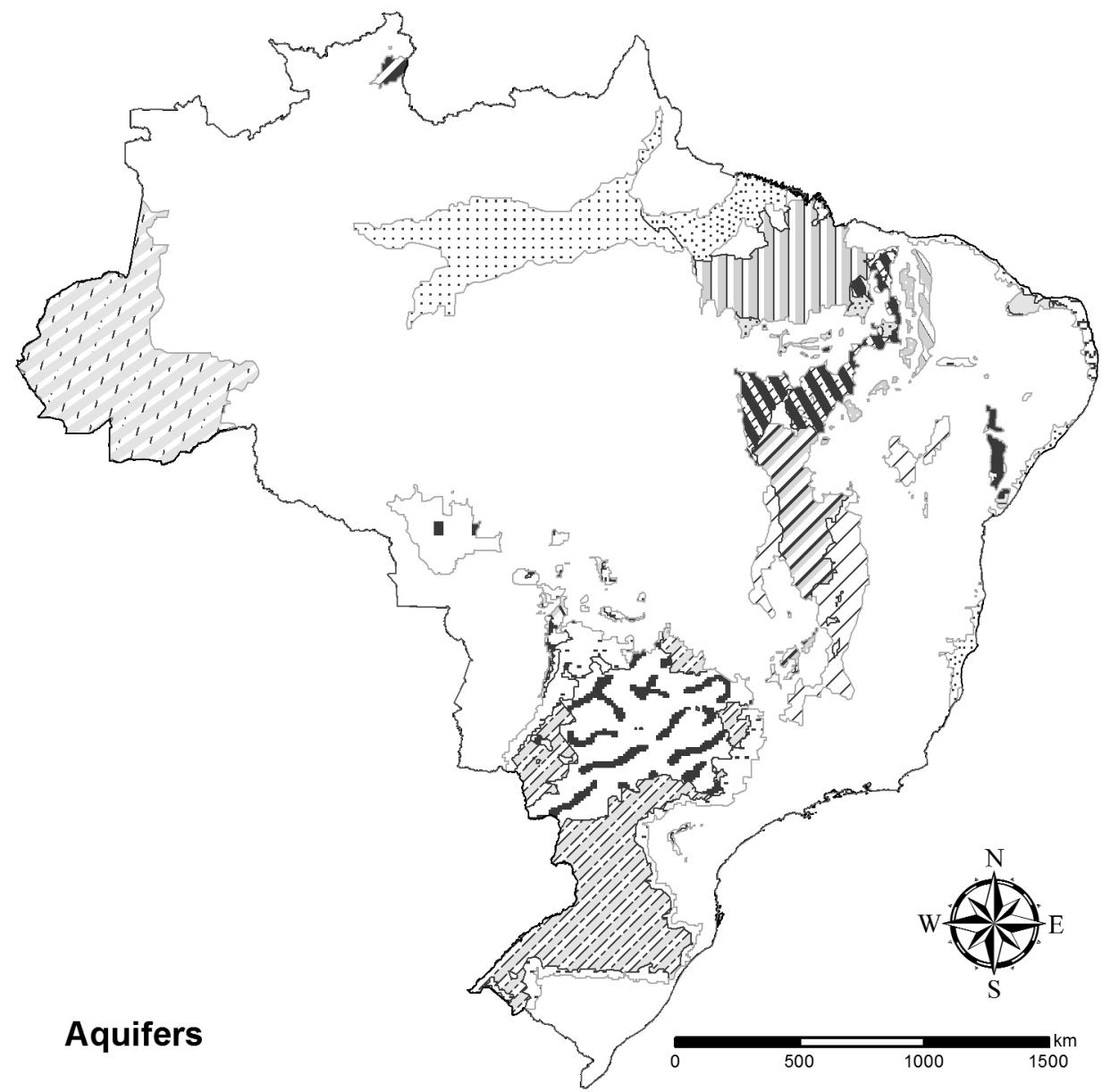

Alter do Chão
$\times X X$ Açu
$\square /$ Bambuí
Barreiras
Bauru - Caiuá
Boa Vista
Cabeças
Corda

\begin{tabular}{|c|c|}
\hline $0^{\circ}$ & Exu \\
\hline & Furnas \\
\hline & Guarani \\
\hline & Itapecuru \\
\hline & Jandaíra \\
\hline & | Marizal \\
\hline MN & $\begin{array}{l}\text { Missão Velha } \\
\text { Motuca }\end{array}$ \\
\hline & Parecis \\
\hline
\end{tabular}

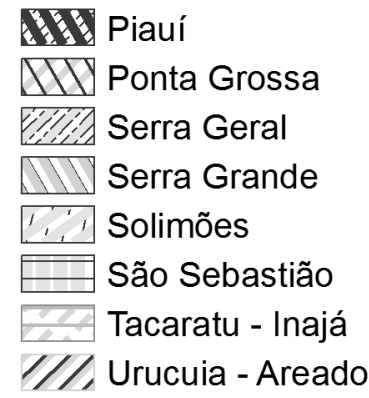

Figure 3 - The major Brazilian aquifer system (Adapted from ANA 2005a).

rainfall can create specific conditions in the soil that reduce infiltration - for example, the formation of crusts on the soil and hydrophobic soils - increasing the surface runoff and reducing the aquifer recharge.

The aquifer recharge reduction, mainly in unconfined aquifers, causes a groundwater decrease in the total available since the safe yield is a fraction of this recharge. Yet, it is certain that a greater exploitation of an aquifer can induce a greater recharge. So, if the dynamics of the aquifer is known, it is possible, with good management practices, to profit the most from this induced recharge increase (and, consequently, from availability), with a better use of the hydric excess by reducing the losses in the base flow. 
A smaller recharge also has a negative impact on the vegetation once the aquifer lowering can reduce soil moisture. A smaller recharge will also cause the saline seawater intrusion in coastal aquifers. This effect is particularly important in large urban centers of the Northeast region (Hirata et al. 2011).

The recharge also plays an important role in diluting contamination caused by disperse sources, including persistent contaminators such as those originated from latrines and pit-latrines in dense urban areas, particularly nitrate. In this case, nitrate elimination is difficult and the dilution with clean water from natural recharge is an effective mechanism to reduce impacts to aquifers. On the other hand, the increase in the aquifer water level can have harmful effects in cities, for example on the foundations of buildings and floods in tunnels, garages and other underground work. This increase can also be harmful to vegetation, with significant alterations in the phreatic level.

Döll and Flörke (2005) present estimates of diffuse recharge in a global scale, with a spatial resolution of $0.5^{\circ}$ to $0.5^{\circ}$. Their study was based on WaterGAP Global Hydrology Model (WGHM) adjusted to arid and semi-arid areas according to independent estimates of the diffuse aquifer recharge. This study estimates with a good approximation (based on calibrations in semi-arid and arid conditions) a reduction of the aquifer recharge, although this model is not yet capable of predicting scenarios with the necessary accuracy, so that results are still uncertain.

In another model, Döll (2009) estimated the climate change impact on the aquifer recharge in a global scale using the most recent code version $2.1 \mathrm{f}$ (Hunger and Döll 2008, Döll and Fiedler 2008) and the two state-of-the-art global data sets of gridded observed precipitation that were corrected for measurement errors, which also allowed to quantify the uncertainty due to these equally uncertain data sets (Döll and Fiedler 2008).
Studies evaluating the influence of climate change on groundwater have been intensified since the 1990's by assessing many impact aspects on the aquifer recharge (Bates et al. 2008, Döll 2009, Döll and Fiedler 2008, Döll and Flörke 2005, Kundzewicz et al. 2008) associated with potential groundwater exploitation scenarios (Loaiciga et al. 2000, Kundzewicz and Döll 2009, Kundzewicz et al. 2007) or with the impact on wetlands or spring yield (Candela et al. 2009). However, the evaluation in the Brazilian or South American territories is still scanty.

Additionally, although all these articles calculated the groundwater recharge in different scale or detail level, almost all authors complained about uncertainties in estimating hydraulic parameters and their interactions in the atmosphere-aquifer system.

In Germany Jankiewicz et al. (2005) evaluated the long-term average groundwater recharge at the scale of $0.5^{\circ}$ grid cells by computing and comparing it to values that were obtained by multiple regression with a spatial resolution of $1 \mathrm{~km}$ by $1 \mathrm{~km}$. The results of this exercise is presented in Figure 4, in which the authors demonstrated that, although there is significant resolution differences, the recharge variations are similar.

Döll and Flörke (2005) obtained four different climate change scenarios for the 2050's. They reached these results based on two predictions of greenhouse gases emissions of IPCC scenarios: A2 and B2 (Nakicenovic and Swart 2000). IPCC scenario A2 is pessimistic, predicting world population growth and the increase of greenhouse gases emissions in current levels. According to this scenario, the average temperature on Earth should rise between $2^{\circ} \mathrm{C}$ and $5.4^{\circ} \mathrm{C}$ until 2100 . The scenario B2 is more optimistic: population and greenhouse gases emissions grow less than in scenario A2. According to it, temperature should rise between $1.4^{\circ} \mathrm{C}$ and $3.8^{\circ} \mathrm{C}$ by 2100 . Climate change scenarios were generated by two climate models: ECHAM4 (Rockner et al. 1996) and HadCM3 (Gordon et al. 2000). More recently 

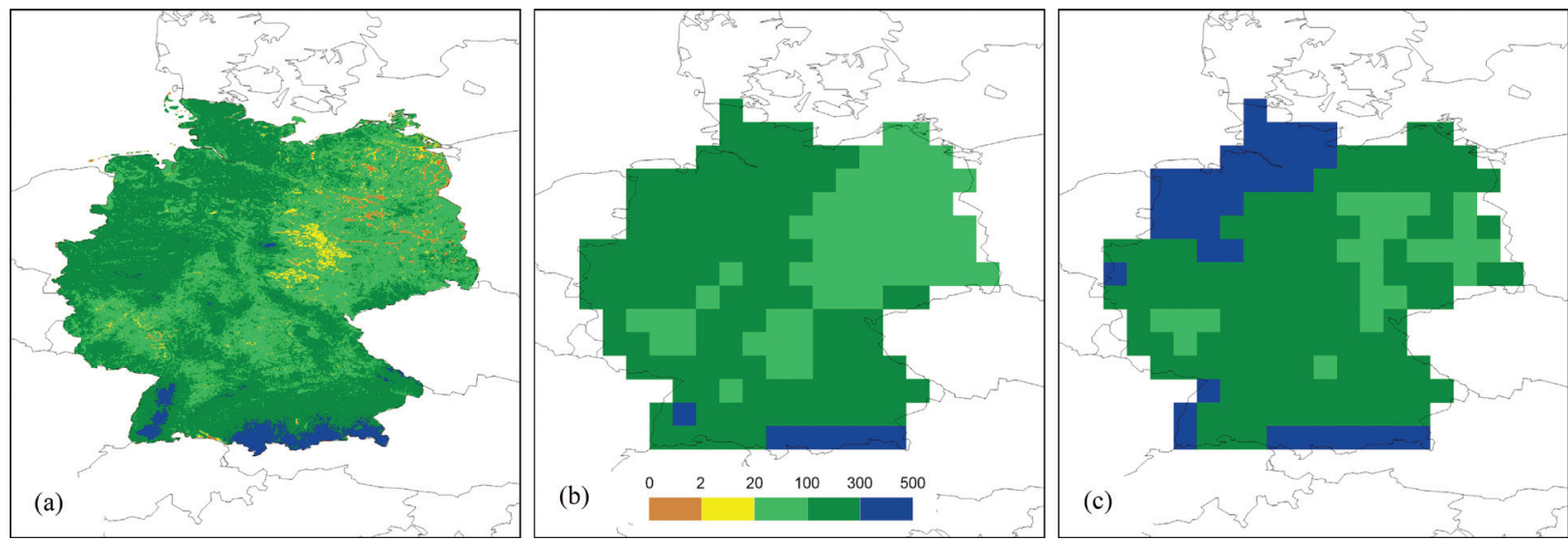

Figure 4 - a) Groundwater recharge in Germany (mm/yr), as computed with a spatial resolution of $1 \mathrm{~km}$ by $1 \mathrm{~km}$ for $1961-1990$; b) aggregated to a spatial resolution of 0.5 ; and c) groundwater recharge as computed with WGHM for the same spatial resolution and time period (from Döll and Fiedler 2008).

Döll (2009), using the same atmospheric models and scenarios, recalculated the recharge, improving her WaterGAP Global Hydrology Model (WGHM) creating four more new aquifer recharge estimations.

The Hadley Centre Coupled Model (HadCM3) is a general atmosphere-ocean circulation numerical code developed in the United Kingdom, with a $2.5^{\circ}$ latitude and $3.75^{\circ}$ longitude of horizontal resolution, and a 19-level atmosphere component. The horizontal resolution has a global grid of 96 x 73 cells, representing approximately $417 \mathrm{~km} \mathrm{x}$ $278 \mathrm{~km}$ of the surface in the equatorial region, and $295 \mathrm{~km}$ x $278 \mathrm{~km}$ at $45^{\circ}$ latitude (compared to a T42 spectral resolution). Its oceanic component has a horizontal resolution of $1.25^{\circ} \times 1.25^{\circ}$ with 20 levels. HadCM3 has equations discriminated in space and time in grids covering the whole world and integrated with time steps of about 30 minutes.

The European Community-Hamburg (ECHAM) numerical model was developed at the Max Planck Institute for Meteorology and German Climate Computing Centre (DKRZ) and presents 19 hybrid levels and a vertical domain corresponding almost to $10 \mathrm{hPa}$ (equivalent to $30 \mathrm{~km}$ height). The horizontal resolution is $2.8^{\circ} \times 2.8^{\circ}$ in both latitude and longitude, and time steps for dynamics and physics is 24 minutes for the horizontal resolution T42.
Using the results of both models (Döll and Flörke 2005, Döll 2009), it is possible to demonstrate that the most vulnerable areas for climate changes in Brazil are associated to the North and Northeast regions, where the aquifer recharge will decrease considerably. In contrast, the models show that in general the recharge in the South and Southeast regions will increase. Although some punctual differences are observed in these two estimations, the results are still valid for establishing actions to mitigate the problem caused by climate changes.

Figures 5 and 6 show the impact of long-term climate changes on the Brazilian aquifers for 2050 based on the results from Döll and Flörke (2005) and Döll (2009). It is also possible to notice a severe reduction in the recharge values in the aquifers of the Northeast region. This region is the most affected by the climate changes: the values show a reduction of more than $70 \%$ in the Northeast region. The North region will also suffer from the decrease of the aquifer recharge, from $30 \%$ to $70 \%$. Data referring to the South and Southeast regions are more favorable, with an increase in the relative recharge values from $30 \%$ to $100 \%$. However, in part of the states of Paraná and São Paulo, there is a $30 \%$ decrease in the recharge in scenarios generated by the HadCM3. These aquifers are 
directly affected in the recharge variation that will influence, above all, unconfined aquifers.

It is important to stress that short-term and medium-term effects of the recharge variation are more noticeable in unconfined aquifers, little affecting (in regular temporal order) large regional confined aquifers. In particular, the Guarani Aquifer System, due to its dynamics (very low groundwater velocity flow) (Foster et al. 2009), will not be affected in its confined portion (beginning at $50 \mathrm{~km}$ from its recharge area) by climate changes in scales of thousands of years.

As observed in Table II, the areas that will be most negatively affected by climate changes in Brazil in the 2050's are the areas now presenting great vulnerability from the hydrological, hydrogeological and social point of view - one of the poorest regions in the country. Currently, the semi-arid Northeast region suffers from problems caused by very frequent droughts, and its coastal aquifer also has to deal with a contamination problem caused by in situ sanitation and sea-water intrusion. An integrated management program that considers surface and subsurface resources for the region is essential due to the high dependence of the population for groundwater.. The aquifers in Natal (Rio Grande do Norte) are extensively contaminated, which forces the public water company to supply water with high nitrate concentration to the population (Foster et al. 2010). More recently, the same problem has been observed in Fortaleza (Ceará), Recife-Olinda (Pernambuco) and São Luis (Maranhão), among others.

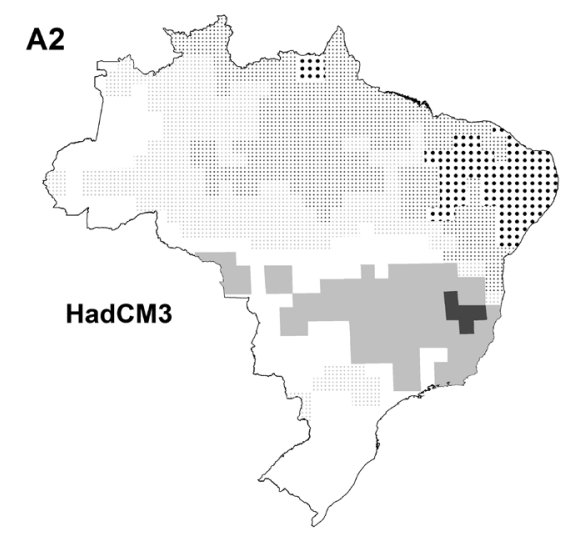

A2
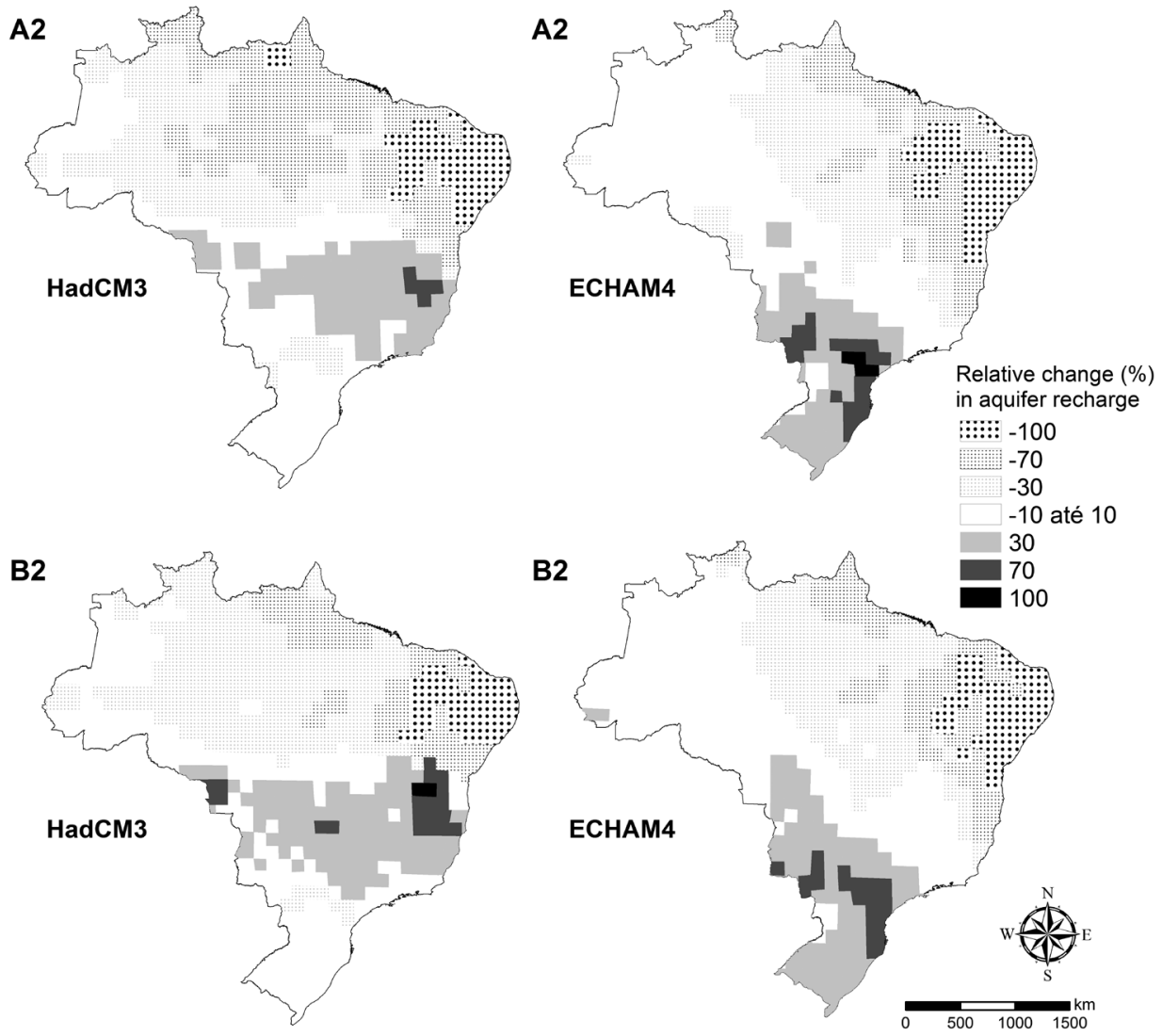

Figure 5 - Long-term climate change impacts on the Brazilian aquifers for 2050 based on the results from Döll and Flörke (2005). Percent variations of 30 years of average recharge between 1961-1990 and 2050 (2041-2070) were calculated by applying WGHM (climate scenarios defined by HadCM3 and ECHAM4, scenarios A2 and B2 for IPCC greenhouse gases emissions.). 

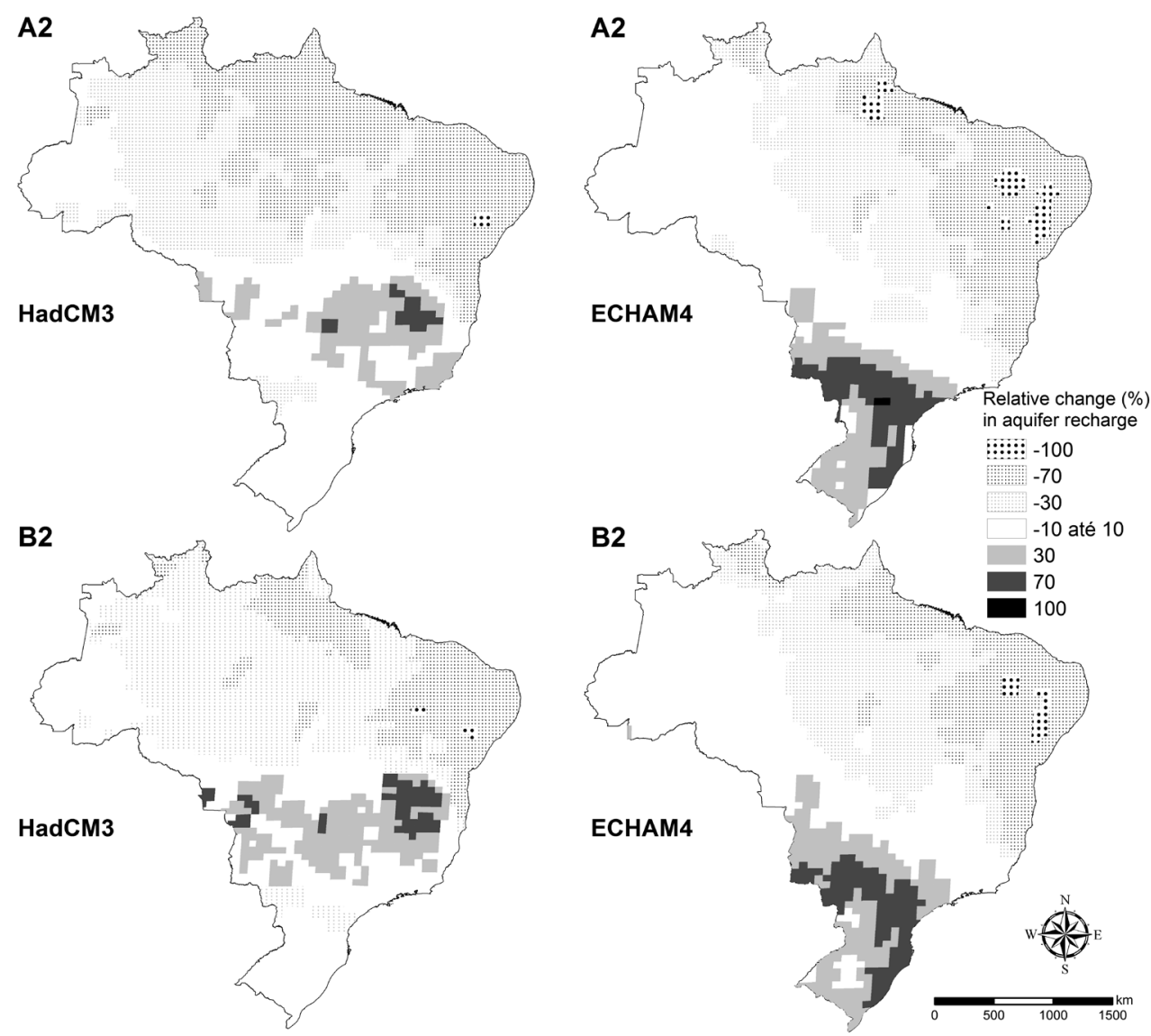

Figure 6 - Long-term climate change impacts on the Brazilian aquifers for 2050 based on the results from Döll (2009). Percent variations of 30 years of average recharge between 1961-1990 and 2050 (2041-2070) were calculated by applying WGHM (climate scenarios defined by HadCM3 and ECHAM4, scenarios A2 and B2 for IPCC greenhouse gases emissions.).

Figure 7 shows the impact of climate changes on the Brazilian territory, taking into account the percentage of territory affected by the variation of the aquifer recharge estimated for the 2050's. This figure also shows that, using HadCM3 A2 and B2 scenarios (based on Döll and Flörke, 2005), more than $50 \%$ of the Brazilian territory will suffer from some kind of recharge reduction until 2050, and $6 \%$ to $8 \%$ of the country area will experience drastic reductions of more than $70 \%$ of recharge. According to the same model, about $25 \%$ to $29 \%$ of the territory will be impacted in $10 \%$ with the increase or reduction in the total recharge volume.

More recently, Döll (2009) reevaluated the results obtained previously in Döll and Flörke (2005) (Figure 7) using the same A2 and B2 scenarios, but modifying hydrogeological recharge model criteria. Although some strong differences are observed in some parts of the world, the recharge in the Brazilian territory will not experience any significant differences.

In the same figure, it is also possible to note that, using another model and scenarios (ECHAM4 A2 and B2), the aquifer recharge will be lesser impacted, and approximately $45 \%$ of the Brazilian territory will suffer from some kind of recharge reduction until 2050 (Döll and Flörke, 2005), with some local, but not important, differences (figure 6). Actually, comparing results from all these models, it is possible to observe that the recharge differences are much more related to the hydrogeological recharge model than to the climate change model or scenario. 
GROUNDWATER AND CLIMATE CHANGE IN BRAZIL

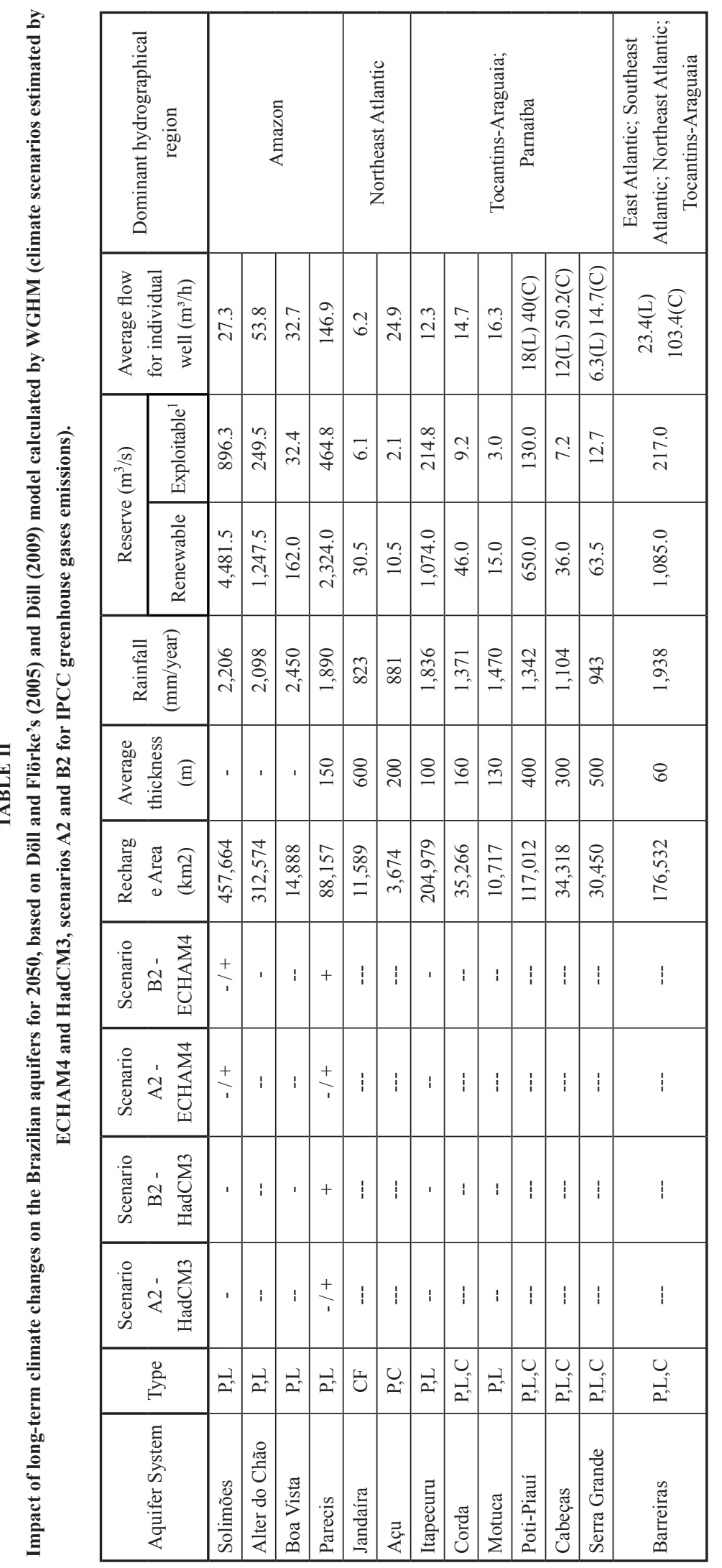




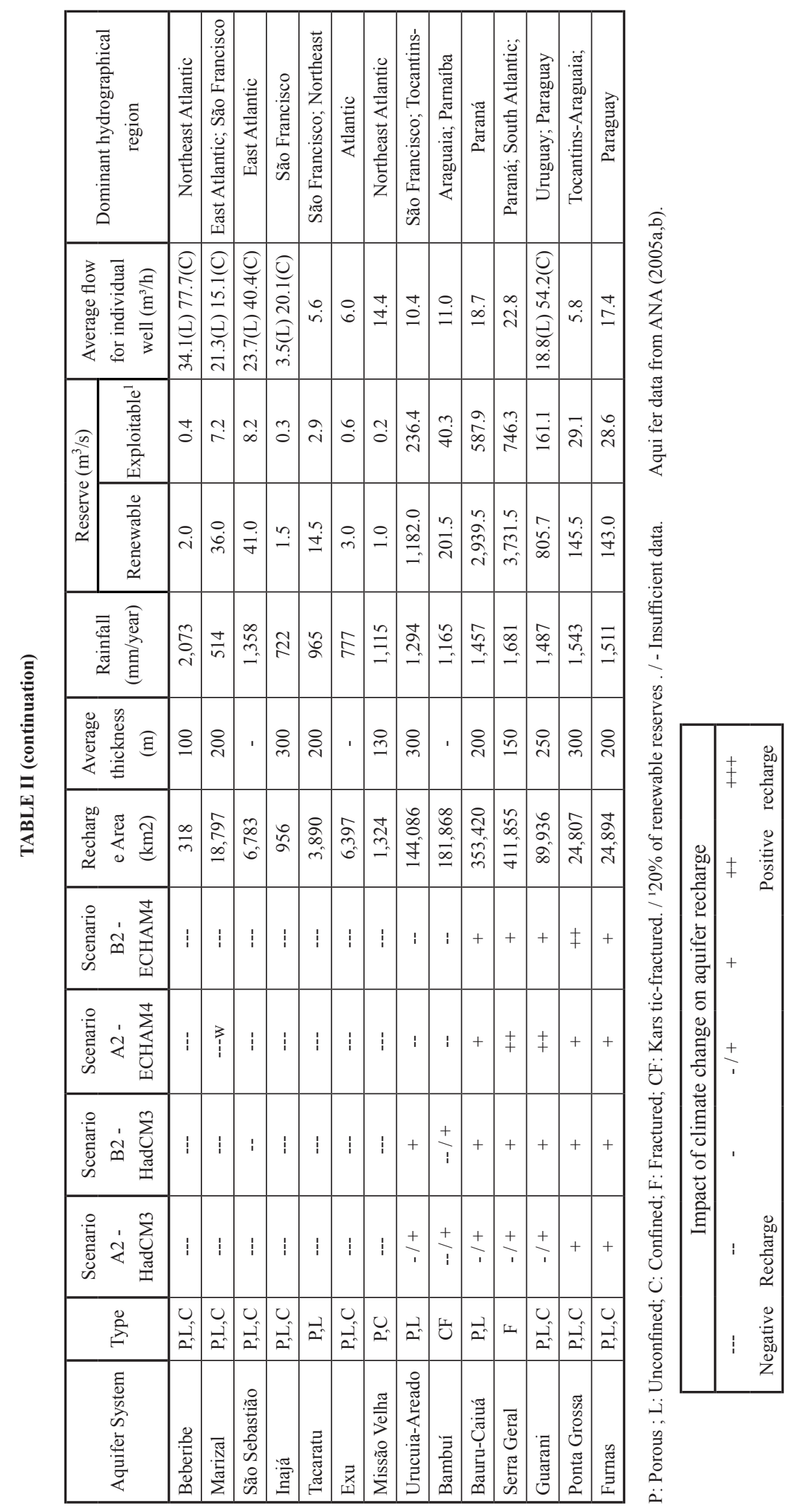




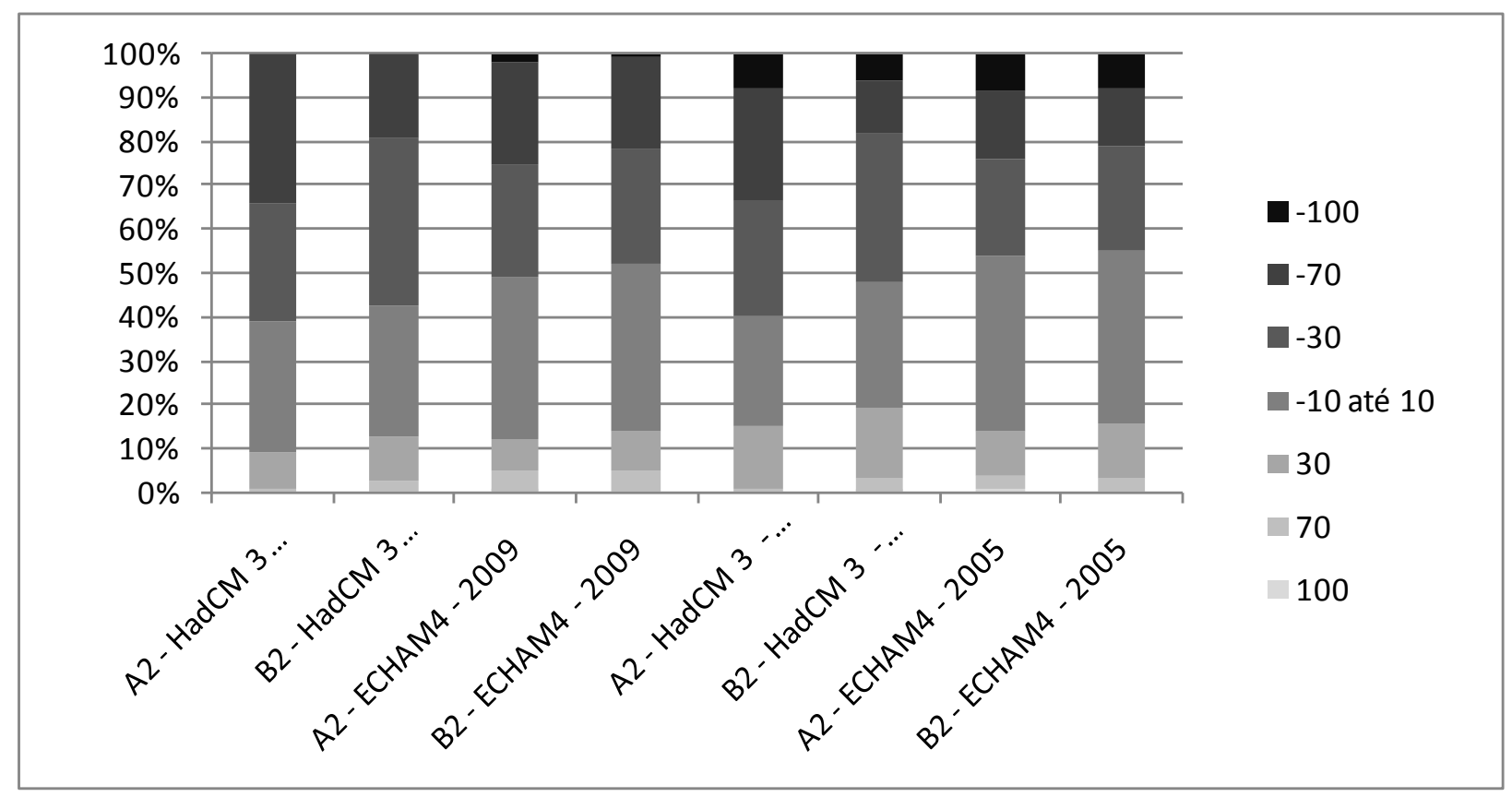

Figure 7 - The impact of climate changes on the Brazilian territory based on the proposal model in percentage of territory affected by the variation of aquifer recharge estimated for 2050 (climate scenarios calculated by ECHAM4 and HadCM3, scenarios A2 and B2 for IPCC greenhouse gases emissions) from Döll and Flörke's (2005) and Döll (2009).

It is necessary to point out that, independently of the model or scenario used, the areas of more recharge reduction will be the same (figures 5 and 6). Both ECHAM4 and HadCM3 (scenarios A2 and B2) present a strong reduction in the North and Northeast regions, the latter being the most affected in Brazil in 2050. On the other hand, positive recharge models coincide in parts of the Brazilian territory, in areas in the South and Southeast regions and in parts of the Mid-West region in ECHAM4. However, models based on HadCM3 show dubious results in the South.

The use of different models for the climate prediction is explained in great part by the uncertainty inherent in each model that is based on physical atmospheric processes, including thermodynamic and dynamic ones, orographic and gravity waves, convection, radiation and atmospheric boundary layer (Gordon et al. 2000).

To visualize the entire effect that climate changes cause on aquifers, it is necessary to analyze a complex combination of factors, including type of soil (and deepness), vegetation, topography and metereological conditions along the year, including the moment and duration of rain, variation of temperature, solar radiation and wind. Among factors influencing the recharge values, the rainfall should be stressed here - its place, moment, and duration. That is why a bigger spatial resolution for South American models is needed, which will reduce the uncertainty as shown by Marengo Orsini (2008), Döll and Flörke (2005) and Döll (2009).

Impacts of climate changes on groundwater are not restricted to more or less water availability, or to the aquifer recharge water quality. The increase in demand and the diminishing supplies of surface water will make the population turn to aquifers as their source of water for public or private uses. In this regard, there is a difference between groundwater and surface water management (Table I). The groundwater extraction has low costs, allowing the private use to have quick and simple access to water of good quality. As a result, in periods of drought, when the decrease in the supply of water occurs, both water price in the public system and the 
number of new wells rise. During a strong drought in the 1990's, many cities in the Northeast region, including Fortaleza and Recife, drastically increased the number of private wells in response to this scarce water problem (Foster et al. 2010, Hirata et al. 2011).

Any adequate management of water necessarily entails knowledge and control of the resource exploitation. Even in states where the law compels to have official permission for the groundwater use, the percentage of illegal wells is higher than $70 \%$ (as in São Paulo). The government organizations responsible for the resource management are inefficient at controlling and inspecting the existing wells and also the new perforations. This problem, associated with the lack of knowledge on the real Brazilian aquifer, potentiality enhances the risk of hydric stress problems.

\section{ACTIONS NEEDED FOR BRAZIL}

Although there has been a growing awareness in the last decade about the groundwater importance for the Brazilian society, the subject has not gained space in the political agenda. The resource management is limited to isolated initiatives that do not reach far enough to guarantee a good (or at least minimum) management of groundwater resources.

As shown in this study, climate changes will affect not only the availability and quality of groundwater, but also the way that the society will have to deal with it. In this context, and still considering the long lack of information and action concerning groundwater in the country, some actions are proposed to be implemented in order to build a water management that helps to overcome potential problems caused by climate changes.

It is necessary to develop specific studies to evaluate the expected impacts of climate changes on groundwater resources, in particular details about recharge and availability of water in the aquifers. For this, it is necessary to characterize the Brazilian aquifers through the hydro- geological cartography, use to strategic pilot areas for real recharge evaluation, to define a way of managing large aquifers (particularly confined systems, for instance, the Guarani Aquifer System) to develop thorough urban hydrogeology studies and to evaluate the groundwater potential for a sustaining irrigated agriculture in areas that will be affected by water scarcity or irregular rainfalls in the future. Study groups formed by hydrogeologists and hydrologists to monitor the aquifers (based on a monitoring well network) and detect earlier climate changes related to these problems must be created. Finally, a special social communication program must be implemented, associated to a constructive relationship among the State, the public concessionary and the groundwater users in order to increase the number of official wells, understand the water uses in urban areas and reduce the impact in aquifers.

\section{CONCLUSIONS}

The groundwater will play a key role in overcoming problems caused by the scarcity due to climate changes. The aquifer reservoir is more resistant to long periods without rain, and it is still little explored in the country.

Climate changes will have some impacts on the groundwater resources, including the recharge reduction especially in the North and Northeast regions. Although there are clear signs of precipitation increase in the South and Southeast regions, the irregularity of this rain can limit the economic development. In this sense, the groundwater can be an important ally by complementing or even replacing the supply based on the surface water. Quality problems will also arise, such as the reduction of coastal aquifer potentiometric levels causing some salt water intrusion problems or even the reduction of the dilution of persistent and mobile contaminators (as nitrate) in unconfined aquifers. 
The solution of these problems is based on three factors: better knowledge on hydraulic and chemical aquifer characteristics; growth of the society awareness and effective management actions. As there are enormous gaps in the knowledge on groundwater resources in the country, priorities must be set regarding the definition of places and knowledge areas that must receive the attention of the government institutions responsible for water resources. These actions must include the improvement of the human resources, the creation of participative management mechanisms (user-State-concessionary) and basic hydrogeological cartography.

\section{RESUMO}

Águas subterrâneas têm um papel estratégico em tempos de mudanças climáticas, principalmente porque os aquíferos podem fornecer água por longos períodos, mesmo durante a seca estiagem muito longa e severa. A redução e / ou alterações no padrão de precipitação pode diminuir a recarga principalmente no aquífero freático, causando restrição de águas subterrâneas disponíveis. O impacto esperado das alterações climáticas de longo prazo sobre os aquíferos brasileiros para 2050 vai levar a uma severa redução em $70 \%$ da recarga nos aquíferos da região Nordeste (comparando aos valores de 2010), variando de 30\% a $70 \%$ na região Norte. Os dados referentes às regiões Sul e Sudeste são mais favoráveis, com um aumento nos valores de recarga relativa de $30 \%$ a $100 \%$. Outro impacto esperado é o aumento da demanda e a diminuição na disponibilidade de água de superfície que vai fazer a população voltar-se para os aquíferos como sua principal fonte de água para uso público ou privado em muitas regiões do país. Assim, um uso integrado de águas superficiais e subterrâneas deve ser considerado no planejamento do uso da água. A solução da escassez de água é baseada em três fatores: $\mathrm{O}$ aumento de conscientização da sociedade, um melhor conhecimento das características hidráulicas e químicas dos aquíferos hidráulicos e químicos e ações eficazes de gestão.
Palavras-chaves: Seca, águas subterrâneas, recarga de aquíferos, uso integrado da água, controle dos recursos hídricos.

\section{REFERENCES}

ANA - AGÊNCIA NACIONAL DE ÁGUAS. 2005a. Panorama da Qualidade das Águas Subterrâneas no Brasil. Brasília. Disponível em: < http://www.ana.gov.br> Acesso em: 11 de janeiro 2010.

ANA - AgÊNCIA NACIONAL de ÁGUAS. 2005b. Disponibilidade e Demandas de Recursos Hídricos no Brasil. Brasília. Disponível em: < http://www.ana.gov.br > Acesso em: 11 de janeiro 2010.

BAtes BC, KundZEWICZ ZW, Wu S AND PALUTIKOF JP. 2008. Climate Change and Water. IPCC Secretariat 210 p. (Technical Paper of the Intergovernmental Panel on Climate Change).

CAMACHO BL AND MARTín JAI. 2000. Las aguas subterrâneas em los abastecimentos: Um decênio de experiências del Canal de Isabel II. Revista de obras públicas. Madrid, n. 3.40(3): 41-56.

Candela L, Von Igela W, Elorzac FJ and Aronica G. 2009. Impact assessment of combined climate and management scenarios on groundwater resources and associated wetland. (Majorca, Spain) J Hydrol doi:10.1016/j.jhydrol.2009.07.057

DöLL P. 2009. Vulnerability to the impact of climate change on renewable groundwater resources: a global-scale assessment. Environ Res Lett, 12 p.

DöLL P AND FIEDLER K. 2008. Global-scale modeling of groundwater recharge. Hydrol Earth Syst Sci 12: 863-885.

DÖLl P AND FLÖRKE M. 2005. Global-Scale Estimation of Diffuse Groundwater Recharge. Frankfurt Hydrology Paper 03, Institute of Physical Geography, Frankfurt University, Frankfurt am Main, Germany, 21 p.

Foster S, HiRATA R, MisRa S AND GARDUÑO H. 2010. Urban groundwater use policy: balancing the benefits and risks in developing nations. Strategic Overview Series. Number 3. The World Bank. Washington (DC), $36 \mathrm{p}$.

Foster S, HiRATA R, VidAl A, SCHMidT G AND GARDUÑo H. 2009. The Guarani Aquifer Initiative - Towards realistic groundwater management in a transbondary context. Case Profile Collection 9. Sustainable Groundwater Management: Lessons from Practice. The World Bank. Washington (DC), $26 \mathrm{p}$.

Gordon C, COOPER C, SENIOR CA, BANKS H, GREGORY JM, Johns TC, Mitchell JFB AND WoOd RA. 2000. The simulation of SST, sea ice extents and ocean heat transports in a version of the Hadley Centre coupled model without flux adjustments. Climate Dynamics 16(2/3): 147-168.

Hirata R, Ferrari L, Ferreira L AND Pede M. 2002. La explotación de las aguas subterráneas en la cuenca hidrográfica del Alto Tietê: crónica de una crisis anunciada. Boletín Geológico y Minero, Madrid 113(3): 273-282. 
HiRATA R, Foster S AND Oliviera F. In press. Águas Subterrâneas Urbanas no Brasil uma avaliação crítica para o desenvolvimento de políticas sustentáveis de gestão. Serie água vol. 7 Banco Mundial, Brasília.

Hirata R, Zobbi JL, Fernandes A And Bertolo RA. 2006. Hidrogeología del Brasil: Una breve crónica de las potencialidades, problemática y perspectivas. Boletín Geológico y Minero, Madrid 217(1): 25-36.

HiRATA R, ZOBY JLG AND OLIVEIRA FR. In press. Recursos hídricos: Uma Visão Estratégica. Água subterrânea: reserva estratégica ou emergencial.

Hunger M AND DöLL P. 2008. Value of river discharge data for global-scale hydrological modeling Hydrol. Earth Syst Sci 12: 841-861.

IBGE - INSTITUTO BRASILEIRO DE GEOGRAFIA E EstATÍSTICA. 2002. Pesquisa Nacional de Saneamento Básico - 2000. Rio de Janeiro: IBGE, CDROM.

IPCC - InTERgovernmental PANel on Climate Change. 2007. Climate Change 2007: Synthesis Report. IPCC, Geneva, Switzerland, 104 p.

JANKIEWICZ P, NEUMANN J, DUIJNISVELD WHM, WESSOLEK G, WyCisK P AND HenNings V. 2005. Abflusshöhe Sickerwasserrate Grundwasserneubildung- Drei Themen im Hydrologischen Atlas von Deutschland. Hydrologie und Wasserbewirtschaftung 49: 2-13.

KUNDZEWICZ ZW AND DöLL P. 2009. Will groundwater ease freshwater stress under climate change? Hydrol Sci J 54: 665-675.

KundZEWicZ ZW, MATA LJ, ARnELl NW, Döll P, JimENEZ B, Miller K, OKI T, SEN Z AND ShIKLOMANOV I. 2008. The implications of projected climate change for freshwater resources and their management Hydrol Sci J 53: 3-10.

KundZewicz ZW, Mata LJ, ARnell NW, DÖll P, Kabat P, JiM'ENEZ B, MILlER KA, OKI T, SEN Z AND SHIKLOMANOV IA. 2007. Freshwater Resources and Their Management Climate Change 2007: Impacts, Adaptation and Vulnerability Contribution of Working Group II to the Fourth Assessment Report of the Intergovernmental Panel on Climate Change, Parry ML, Canziani OF, Palutikof JP, van der Linden PJ and Hanson CE (Eds), Cambridge: Cambridge University Press, p. 173-210.
LOAICIGA HA, MAIDMENT DR AND VALDES JB. 2000. Climatechange impacts in a regional karst aquifer. Texas, USA J Hydrol 227: 173-194.

MARENGo Orsini JA. 2008. Água e mudanças climáticas. Scielo 22(63): 83-96. Disponível em: <http://www.scielo.br/ scielo.php?script $=$ sci arttext\&pid $=\mathrm{S} 01034014200800020$ 0006\&lng=en\&nrm=iso $>$. Acesso em: 11 de janeiro 2010

MiLly PCD, DunNE KA AND VECCHIA AV. 2005. Global pattern of trends in streamflow and water availability in a changing climate. Nature 438: 347-350.

NAKICENOVIC NAND SWART R. 2000. Emission Scenarios. IPCC Special Report on Emission Scenarios. Cambridge University Press. Disponível em: <http://www.ipcc.ch> Acesso em: 10 de janeiro 2010.

QUEIROZ ET. 2004. Diagnóstico de águas minerais e potáveis de mesa do Brasil. In: CONGRESSO BRASILEIRO DE ÁGUAS SUBTERRÂNEAS, 13. Cuiabá: ABAS, 2004. CD-ROM.

REBOUÇAS A. 1999. Águas Subterrâneas. In: REBOUÇAS A, BRAGA B and TUNDISI J (Eds), Águas Doces no Brasil: capital ecológico, uso e conservação. São Paulo, Escrituras Editora, p. 117-150.

Rockner E, Arpe K, BengtSSON L, Christoph M, ClaUsSEN M, DÜMEnil L, Esch M, GioRgetta M, Schlese U AND SChulzweIDA U. 1996. The atmospheric general circulation model ECHAM-4: Model description and simulation of present day climate, MPIReport No. 218, MPI für Meteorologie, Hamburg. Disponível em: $<$ www. mpimet.mpg.de $>$. Acesso em: 11 de janeiro 2010.

Silva MFB, NicoletTi A, RocCA ACC AND CASARINI DCP. 1998. Uso e qualidade das águas subterrâneas para abastecimento público no Estado de São Paulo. In: CONGRESSO BRASILEIRO DE ÁGUAS SUBTERRÂNEAS, 10. São Paulo. ABAS, CD-ROM. 